\title{
Resistance of stainless steel CHS columns based on cross-section deformation capacity
}

\author{
Mahmud Ashraf ${ }^{1}$, Leroy Gardner ${ }^{2}$, David A Nethercot ${ }^{3}$
}

1 Assistant Professor, Department of Civil Engineering, Bangladesh University of Engineering and Technology, Dhaka - 1000, Bangladesh.

mashraf@ce.buet.ac.bd,mahmud.ashraf02@imperial.ac.uk

2 Corresponding author

Senior Lecturer in Structural Engineering, Department of Civil and Environmental Engineering, Imperial College London, London SW7 2AZ.

leroy.gardner@imperial.ac.uk

3 Professor and Head, Department of Civil and Environmental Engineering, Imperial College London, London SW7 2AZ.

d.nethercot@imperial.ac.uk 


\section{Abstract}

A conceptually new structural design approach has recently been proposed by the authors to predict the resistance of stainless steel members subjected to various types of loading with cross-sections formed from thin flat plates including angles, channels, lipped channels, I sections and rectangular hollow sections (RHS). The proposed method does not follow the traditional cross-section classification approach, which primarily relies on the assumption of a bilinear, elastic-perfectly-plastic material model. Instead, deformation capacity of a cross-section is determined directly from the local buckling characteristics of the constituent plate elements. This is then used to obtain the corresponding local buckling stress utilising an appropriate material model. This basic concept is extended herein to predict compression resistance of stainless steel columns with circular hollow sections (CHS). Available test and finite element (FE) results have been used to develop the basic design equation to predict the compression resistance of cross-sections and to propose column curves to determine flexural buckling resistances. The predicted resistances have been compared to those obtained using the current Eurocode; the predictions are significantly more accurate and more consistent than those given by the existing Eurocode.

\section{Keywords}

Circular hollow section (CHS); Columns; Compression resistance; Cross-section slenderness; Deformation capacity; Flexural buckling; Stainless steel; Stub column 


\section{Introduction}

Stainless steel has a number of established benefits over carbon steel, but attracts a higher material cost [1]. There is therefore greater incentive for structural design processes to utilise the available strength to the full. Largely due to a lack of data, the custom to date $[2,3]$ has been to adapt procedures for carbon steel with little regard for differences in behaviour of stainless steel components. Recently, the authors have incorporated several special features of stainless steel - the rounded stress-strain curve and greater strength in the corner regions - in a new approach that provides more accurate and more consistent predictions of performance than do current Codes [4]. To date the procedure has been almost exclusively restricted to cross-sections composed of an assembly of flat plates. However, the method is general in concept and is extended herein, following the proposals of Gardner and Nethercot [5], to deal with circular hollow sections (CHS). Although the approach is validated only for CHS cross-sections in compression and for axially loaded CHS columns, the general principles are capable of application to more general loading arrangements [4] and to closed sections having more general shapes; the absence of suitable experimental and numerical results currently prevents that generalisation.

\section{Tests performed on CHS columns}

All available stainless steel CHS column tests have been considered in this paper to devise a basic design curve giving the relationship between deformation capacity and slenderness of cross-sections and to validate subsequent design rules, following the approach proposed by Gardner and Nethercot [5]. A brief overview of each set of tests follows. Rasmussen and Hancock [6] conducted tensile and compressive tests on material coupons and 
buckling tests on stainless steel SHS and CHS produced from austenitic grade EN 1.4306 material. Talja [7] reported tests performed on welded I-section and CHS beams, columns and beam-columns. Tensile tests were carried out on coupons cut from the specimens, which were produced from austenitic grade EN 1.4435 material. Young and Hartono [8] conducted a series of tests on stainless steel CHS fixed-ended columns produced from austenitic grade EN 1.4301 material. Average results obtained from the supporting tensile tests on material coupons were also reported. Gardner [9] carried on an extensive testing programme involving tubular stainless steel beams and columns. All tested SHS, RHS and CHS sections were produced from austenitic grade EN 1.4301 material. The stress-strain characteristics of the material under both compression and tension were also investigated. All relevant experimental results were reported by Gardner and Nethercot $[10,11]$. Recently, Bardi and Kyriakides [12] carried out compression tests on stainless steel CHS stub columns with varying diameter-to-thickness ratios. Average material properties for duplex grade EN 1.4410 material obtained from tensile coupon tests were also reported. Lam and Roach [13], as a part of their testing scheme on concrete filled stainless steel tubes, performed compression tests on 2 unfilled stainless steel CHS stub columns. Tensile material tests were conducted on coupons cut from the austenitic grade EN 1.4401 tubes. From the experimental programmes summarised above, a total of 35 fix-ended stub column test results were collated.

Cross-section slenderness $\beta$ for each of these 35 test specimens has been determined using Equation 1, which includes both geometrical and material properties. Table 1 presents a summary of the data showing the variations in material type and also in cross-section slenderness; $\beta$ varies from 0.012 to 0.106 covering all traditional classes i.e. Class 1 to 4 . 


$$
\beta=\frac{1}{2}\left(\frac{\mathrm{D}}{\mathrm{t}}-1\right) \frac{\sigma_{0.2}}{\mathrm{E}_{0}}
$$

where $\mathrm{D}$ and $\mathrm{t}$ are the outer diameter of the cross-section and the thickness of the plate, respectively and $\sigma_{0.2}$ and $\mathrm{E}_{0}$ are the $0.2 \%$ proof stress and the initial modulus of the material stress-strain response, respectively.

\section{Finite element modelling of the stub column response}

All aforementioned stub column test results have been modelled using the finite element (FE) package ABAQUS 6.4 (2003). Stress-strain behaviour has been represented using the modified compound Ramberg-Osgood formulations, proposed by Gardner and Ashraf [14], as given by Equations 2 and 3, to accurately predict the pronounced nonlinearity of stainless steel.

$$
\begin{array}{ll}
\varepsilon=\frac{\sigma}{\mathrm{E}_{0}}+0.002\left(\frac{\sigma}{\sigma_{0.2}}\right)^{\mathrm{n}} & \text { for } \sigma \leq \sigma_{0.2} \\
\varepsilon=\frac{\left(\sigma-\sigma_{0.2}\right)}{\mathrm{E}_{0.2}}+\left(\varepsilon_{\mathrm{t} 1.0}-\varepsilon_{\mathrm{t} 0.2}-\frac{\sigma_{1.0}-\sigma_{0.2}}{\mathrm{E}_{0.2}}\right)\left(\frac{\sigma-\sigma_{0.2}}{\sigma_{1.0}-\sigma_{0.2}}\right)^{\mathrm{n}_{0.21 .0}}+\varepsilon_{\mathrm{t} 0.2} & \text { for } \sigma>\sigma_{0.2}
\end{array}
$$

where $\mathrm{E}_{0}$ and $\mathrm{E}_{0.2}$ are the Young's modulus and the tangent modulus at $0.2 \%$ offset strain, respectively, $\sigma_{0.2}$ and $\sigma_{1.0}$ are the proof stresses at $0.2 \%$ and $1 \%$ offset strains, respectively, $\varepsilon_{t 0.2}$ and $\varepsilon_{t 1.0}$ are the total strains at $\sigma_{0.2}$ and $\sigma_{1.0}$, respectively and $\mathrm{n}$ and $\mathrm{n}_{0.2,1.0}^{\prime}$ are strain hardening exponents, values of which have been proposed for different grades of stainless steel [15]. 
The thin-shell element S9R5 has been used to model the stub columns with all the degrees of freedom restrained at both ends except for the vertical displacement at the loaded edge. Constraint equations were used to ensure that all nodes at the loaded end act as a group to move vertically when a concentrated load was applied to one of the nodes. Initial geometric imperfections were introduced using the first Eigenmode obtained from the elastic analysis with an appropriate amplitude $-0.02 \mathrm{t}$ for the stub columns tested by Bardi and Kyriakides [12] as this closely approximates the reported values and $0.2 \mathrm{t}$ for all other cases (where no specific information is available), which has been proposed as a general guideline for stainless steel CHS stub columns by Gardner and Nethercot [16]. The ultimate load capacity for each of the stub columns obtained from the nonlinear analysis using the Riks method has been compared to the experimental results. For 35 stub columns, the FE predictions were, on average, $96 \%$ of the test results with a coefficient of variation $(\mathrm{COV})$ of 0.10 . Figure 1 compares the FE predictions to the corresponding test results. Three of the test results, in particular, were not accurately predicted by the FE models. Two tests reported by Young and Hartono [8] were overpredicted, whilst one test reported by Lam and Roach [13] was underpredicted. The remaining results show better consistency with a COV of only 0.06 . Given that the FE models have been developed using predicted [15] stain hardening coefficients $\mathrm{n}$ and n'0.2,1.0 for different grades (since experimental values were not available for each case), the agreement can be considered acceptable. The overall prediction is dominated by 20 results for duplex grade EN 1.4410 reported by Bardi and Kyriakides [12], for which the key parameters in material modelling $\mathrm{n}, \mathrm{n}^{\prime}$ and $\sigma_{1.0} / \sigma_{0.2}$ were taken as 4.0, 3.4 and 1.15, respectively, as proposed by Ashraf et al [15]; these values were based on duplex grade EN 1.4462. Ashraf [17] observed that the $\sigma_{1.0} / \sigma_{2.0}$ ratio significantly affects the material response and thus the cross-sectional loadend shortening behaviour. Hence accurate (measured) values for the compound Ramberg- 
Osgood parameters for duplex grade EN 1.4410 material would have produced even better agreement.

The stub columns tested by Bardi and Kyriakides [12] were very short and hence may not represent the actual load deformation behaviour of a stub column, which should have a minimum length of 3 times the largest cross-sectional dimension [18]. Therefore, these cross-sections were used to model typical stub columns with $\mathrm{L}=3 \mathrm{D}$, where $\mathrm{D}$ is the diameter, and the corresponding deformation capacities were noted for use in devising the basic design curve for compression resistance as explained in the following section.

\section{Compression resistance of cross-sections using its deformation capacity}

Gardner and Nethercot [5] proposed a conceptually new approach to determine crosssectional resistances based on deformation capacity as measured by the axial strain corresponding to the failure load of a stub column. Initially, the method was limited to tubular cross-sections. Further investigations $[17,19,4]$ successfully extended the scope of the proposed concept to cover open cross-sections i.e. angles, channels, lipped channels and I sections. The authors have already proposed a generalised equation for all stainless steel cross-section types formed from flat plates, which can accurately predict compression resistance without using the traditional cross-section classification.

Figures 2 and 3 show the normalised deformation capacity $\varepsilon_{\mathrm{LB}} / \varepsilon_{0}$ against the cross-section slenderness $\beta$ for all test and FE results of Table 1. Previous FE results for stainless steel CHS stub columns [9] have also been included in Figure 3. The results are compared to 
the design curve proposed by Gardner and Nethercot [5] for stainless steel CHS as given by Equation 4.

$$
\frac{\varepsilon_{\mathrm{LB}}}{\varepsilon_{0}}=\frac{0.116}{\beta^{1.21 \beta+1.69}}
$$

Figure 2 shows that the deformation capacities for the very short $(\mathrm{L} \approx 1.5 \mathrm{D})$ stub columns tested by Bardi and Kyriakides [12] are generally higher than those predicted by Gardner and Nethercot's [5] proposed curve and other test data. Hence the performance of the design curve was compared with the FE predictions of the Bardi and Kyriakides tests (with a FE model length of $\mathrm{L}=3 \mathrm{D}$ rather than the test length of $\mathrm{L}=1.5 \mathrm{D}$, for reasons described in Section 3 of this paper). The results are shown in Figure 3, where it may be observed that the FE results lie marginally below the proposed design equation, but closely follow the trend of the overall data set and exhibit less scatter.

Once the local buckling strain $\varepsilon$ LB for a cross-section has been determined using Equation 4, the corresponding local buckling stress $\sigma_{L B}$ can be obtained either by using the design tables [17] or by using the inverse expressions for the compound Ramberg-Osgood material model as proposed by Abdella [20]; the detailed process has been explained in Ashraf et al [4]. The compression resistance $\mathrm{N}_{\mathrm{c}, \mathrm{Rd}}$ is thus given by Equation 5 .

$$
\mathrm{N}_{\mathrm{c}, \mathrm{Rd}}=\mathrm{Ag}_{\mathrm{g}} \sigma_{\mathrm{LB}}
$$

where $\mathrm{Ag}_{\mathrm{g}}$ is the gross area of the cross-section. Equation 5 may be applied to the full range of cross-section slenderness, including those traditionally classified as slender (Class 4). 
Compression resistances for all the considered stub columns have been predicted following both the proposed approach and the EN 1993-1-4 (2006) [2] guidelines. It is worth mentioning that EN 1993-1-4 (2006) does not provide guidance for calculating the effective area for Class 4 cross-sections. Hence the British Standard BS 5950: Part 1 [21] effective area formulation has been adopted. It should be noted that, in the absence of a simple effective area expression in Eurocode 3, the BS 5950 expression was modified by Trahair et al [22] and recommended for application to slender steel CHS.

Table 2 presents the calculated values for the key parameters and compares the predicted resistances to the test and FE results. The proposed method predicts $98 \%$ of the compression resistance on average with a COV of 0.09, whilst EN 1993-1-4 (2006) approach can predict only $80 \%$ with a COV of 0.12 - this clearly shows the improved accuracy of the proposed technique over the Eurocode. Figure 4 shows the performance of the deformation capacity based approach for different cross-section slendernesses, whilst Figure 5 compares its performance with the Eurocode.

\section{Flexural buckling resistance of CHS columns}

Results from a total of 22 stainless steel CHS column buckling tests performed by Rasmussen and Hancock [6], Talja [7] and Young and Hartono [8] have been analysed and used to evaluate the performance of the flexural buckling curve provided in EN 19931-4 (2006). The Eurocode adopts multiple column curves with specific values for imperfection factor $\alpha$ and limiting slenderness ratio $\bar{\lambda}_{0}$ for different cross-section types; for stainless steel hollow cross-sections, the values for $\alpha$ and $\bar{\lambda}_{0}$ are 0.49 and 0.40 respectively. For the 22 columns considered, Eurocode over-predicted the test flexural 
buckling resistances with an average $\mathrm{EN} \mathrm{F}_{\mathrm{u}} / \mathrm{Test}_{\mathrm{u}}$ of 1.07 and a $\mathrm{COV}$ of 0.09 . Further FE results were available for 36 fixed-ended long columns reported by Young and Ellobody [23]. The cross-sections were all slender with D/t ratios ranging between 100 and 200. When the flexural buckling resistances for these columns were predicted using the EN 1993-1-4 (2006) guidelines with the effective areas from BS 5950, the average prediction was 0.84 with a higher scatter $(\mathrm{COV})$ of 0.18 .

Ashraf et al [24] proposed a new approach to predict column buckling resistance including the effects of material nonlinearity and strain hardening, yet retaining the basic form of the Eurocode guidelines. The proposed method follows the continuous approach (i.e. no traditional classification is required) adopted for cross-section resistance. A new

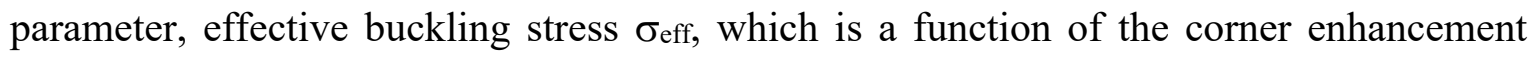
factor $\phi_{c}, 0.2 \%$ proof strength of the flat material $\sigma_{0.2}$ and local buckling stress of the cross-section $\sigma_{\mathrm{LB}}$, was defined. In the case of CHS, $\phi_{\mathrm{c}}$ can be taken as 1.0 since there are no cold-worked corners in CHS. Thus, the effective buckling stress for stainless steel CHS can be expressed by Equation 6, and the flexural buckling resistance $\mathrm{Nb}_{\mathrm{b}, \mathrm{Rd}}$ should be determined using Equation 7, with the values for all required parameters i.e. buckling reduction factor $\chi$, operational parameter $\phi$ and non-dimensional slenderness of the column $\bar{\lambda}$ calculated using Equations 8, 9 and 10 respectively.

$$
\begin{gathered}
\sigma_{\text {eff }}=\left[\begin{array}{ll}
\sigma_{0.2} & \sigma_{\mathrm{LB}}
\end{array}\right]^{0.5} \\
\mathrm{~N}_{\mathrm{b}, \mathrm{Rd}}=\chi \mathrm{Ag}_{\mathrm{g}} \sigma_{\mathrm{eff}}
\end{gathered}
$$




$$
\begin{aligned}
& \chi=\frac{1}{\phi+\sqrt{\phi^{2}-\bar{\lambda}^{2}}} \leq 1.0 \\
& \phi=0.5\left[1+\alpha\left(\bar{\lambda}-\bar{\lambda}_{0}\right)+\bar{\lambda}^{2}\right] \\
& \bar{\lambda}=\sqrt{\frac{\mathrm{A}_{\mathrm{g}} \sigma_{\text {eff }}}{\mathrm{N}_{\mathrm{cr}}}}
\end{aligned}
$$

Appropriate values for the imperfection factor $\alpha$ and the limiting slenderness ratio $\bar{\lambda}_{0}$ were obtained through regression analysis. The obtained values for $\alpha$ and $\bar{\lambda}_{0}$ were 0.49 and 0.05 respectively. Figure 6 compares the proposed and the current Eurocode flexural buckling curves together with the considered test results.

Flexural buckling resistances for all 22 test results and $36 \mathrm{FE}$ results have been predicted using the proposed method; average prediction for the test results was 1.00 with a COV of 0.07, whilst those for the FE results are 0.99 and 0.05 showing a significant improvement both in average and scatter over the Eurocode. Detailed comparisons are given in Tables 3 and 4, whilst Figures 7 and 8 compare the performance of the proposed method against test results and the Eurocode.

\section{Conclusions}

The scope of a design method, originally proposed by the authors for stainless steel members with cross-sections formed from flat plates, has been extended to cover stainless steel Circular Hollow Sections (CHS). The novel feature of this approach is that it does 
not require classification of cross-sections but is based on a continuous relationship between the slenderness of a cross-section and its deformation capacity. Used in conjunction with the local buckling strain, a compound Ramberg-Osgood material model provides accurate values for the local buckling stress of a cross-section. The concept is extended further to determine flexural buckling resistances for long columns based on Perry type column curves. Appropriate values for the imperfection factor $\alpha$ and the limiting slenderness ratio $\bar{\lambda}_{0}$ are then used to determine accurate buckling reduction factors for CHS long columns.

Overall, the proposed design method offers accurate and consistent prediction of the resistance of tested CHS stub columns, in contrast to the highly conservative and scattered predictions of Eurocode. In the case of long columns, the proposed method again provides accurate predictions of test resistances, whilst the Eurocode guidelines result in overprediction of the considered test results.

The proposed concept of 'resistance based on deformation capacity' has already been shown to perform well for all cross-section types formed of thin flat plates. Now that this concept has been verified for CHS members, it is envisaged that the proposed design method could be developed as a complete design tool providing more efficient structural design for stainless steel and thus helping to promote its wider use in construction.

\section{References}

[1] Gardner, L. (2005). The use of stainless steel in structures. Progress in Structural Engineering and Materials. 7(2): 45-55. 
[2] EN 1993-1-4 (2006). Eurocode 3: Design of Steel Structures. Part 1.4: General rules Supplementary rules for stainless steel. CEN.

[3] SEI/ASCE (2002). Specifications for the design of cold-formed stainless steel structural members. SEI/ASCE 8-02. American Society of Civil Engineers.

[4] Ashraf, M., Gardner, L and Nethercot, D. A. (in press). Structural stainless steel design: Resistance based on deformation capacity. Journal of Structural Engineering, ASCE.

[5] Gardner, L. and Nethercot, D. A. (2004). Structural stainless steel design: A new approach. The Structural Engineer. 82(21): 21-28.

[6] Rasmussen, K. J. R. and Hancock, G. J. (1993). Design of cold-formed stainless steel tubular members. I: Columns. Journal of Structural Engineering, ASCE. 119(8): 23492367.

[7] Talja (1997). Test report on welded I and CHS beams, columns and beams-columns. Report to ECSC. VTT Building Technology, Finland.

[8] Young, B. and Hartono, W. (2002). Compression tests of stainless steel tubular members. Journal of Structural Engineering, ASCE. 128(8): 754-761. 
[9] Gardner, L (2002). A new approach to structural stainless steel design. Ph.D. Thesis. Structures Section, Department of Civil and Environmental Engineering. Imperial College London, UK.

[10] Gardner, L. and Nethercot, D. A. (2004). Experiments on stainless steel hollow sections - Part 1 - Material and cross-sectional behaviour. Journal of Constructional Steel Research. 60(9): 1291-1318.

[11] Gardner, L. and Nethercot, D. A. (2004). Experiments on stainless steel hollow sections - Part 2 - Member behaviour of columns and beams. Journal of Constructional Steel Research. 60(9): 1319-1332.

[12] Bardi, F. C. and Kyriakides, S. (2006). Plastic buckling of circular tubes under axial compression - Part I: Experiments. International Journal of Mechanical Sciences. 48(8): $830-841$.

[13] Lam, D. and Roach, C. (2006). Axial capacity of concrete filled stainless steel circular columns. Proceedings of the $11^{\text {th }}$ International Symposium and IIW International Conference on Tubular on Tubular Structures, Tubular Structures XI. 495-501. Quebec City, Canada.

[14] Gardner, L. and Ashraf, M. (2006). Structural design for non-linear metallic materials. Engineering Structures. 28(6): 926-934. 
[15] Ashraf, M., Gardner, L and Nethercot, D. A. (2006a). Finite element modelling of structural stainless steel cross-sections. Thin-Walled Structures. 44(10): 1048-1062.

[16] Gardner, L. and Nethercot, D. A. (2004). Numerical modelling of stainless steel structural components - A consistent approach. Journal of Structural Engineering ASCE, 130(10): 1586-1601.

[17] Ashraf, M. (2006). Structural stainless steel design: Resistance based on deformation capacity. Ph.D. thesis. Department of Civil and Environmental Engineering, Imperial College London, UK.

[18] Galambos, T. V., Editor. (1998). Guide to stability design criteria for metal structures. $4^{\text {th }}$ Edition. Structural Stability research Council. John Wiley and Sons, Inc. New York.

[19] Ashraf, M., Gardner, L and Nethercot, D. A. (2006). Compression strength of stainless steel cross-sections. Journal of Constructional Steel Research. 62(1-2): 105-115.

[20] Abdella, K. (2006). Inversion of a full-range stress-strain relation for stainless steel alloys. International Journal of Non-Linear Mechanics. 41(3): 456-463.

[21] BS 5950-1 (2000). Structural use of steelwork in buildings - Part 1: Code of practice for design in simple and continuous construction: hot rolled sections. British Standards Institution. 
[22] Trahair, N. S., Bradford, M. A., Nethercot, D. A. and Gardner, L. (2007). Behaviour and design of steel structures to EC3. Fourth Edition - British. Spon Press.

[23] Young, B. and Ellobody, E. (2006). Column design of cold-formed stainless steel slender circular hollow sections. Steel and Composite Structures. 6(4): 285-302.

[24] Ashraf, M., Gardner, L., Nethercot, D. A. (2006). Column curves for stainless steel sections exploiting its stress-strain behaviour and response to cold-working. Proceedings of the International Colloquium on Stability and Ductility of Steel Structures SDSS 2006, 651-658. Lisbon, Portugal. 


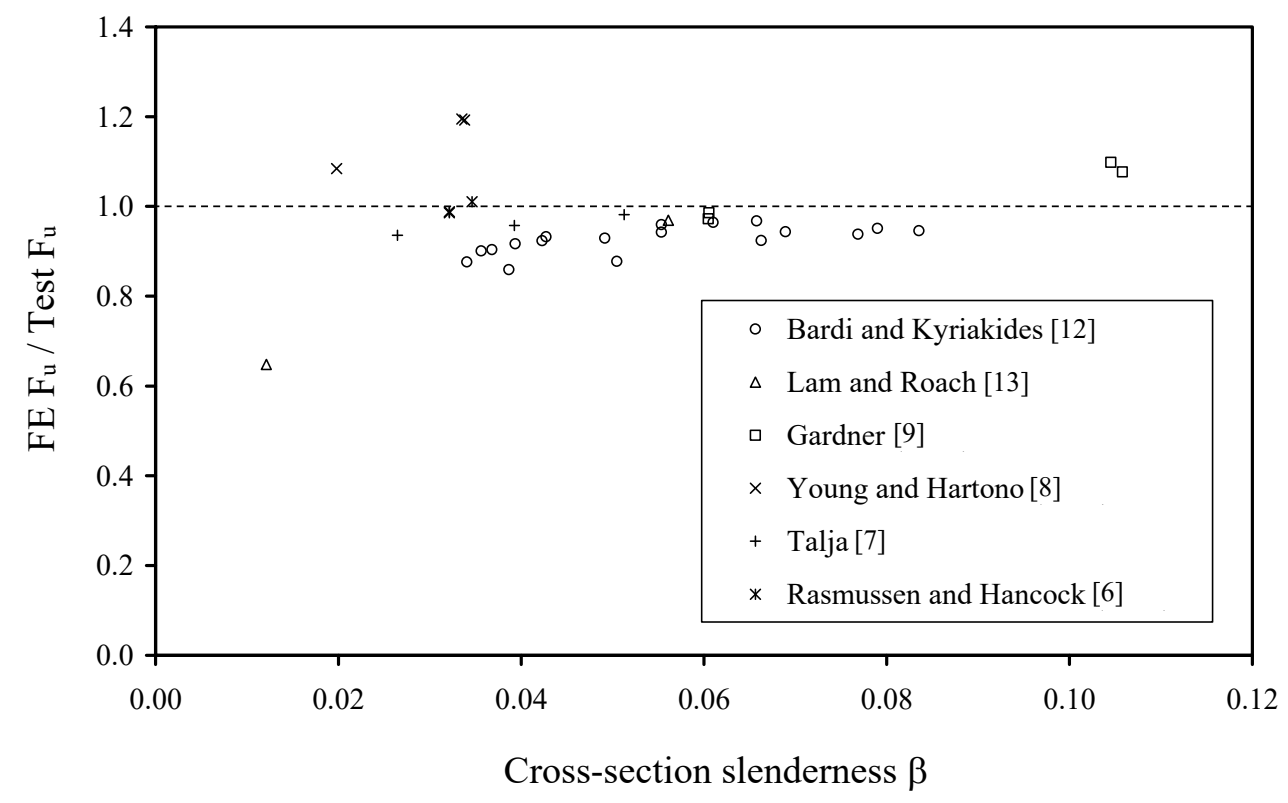

Figure 1: Comparison of FE predictions and test results for stub column compression resistances.

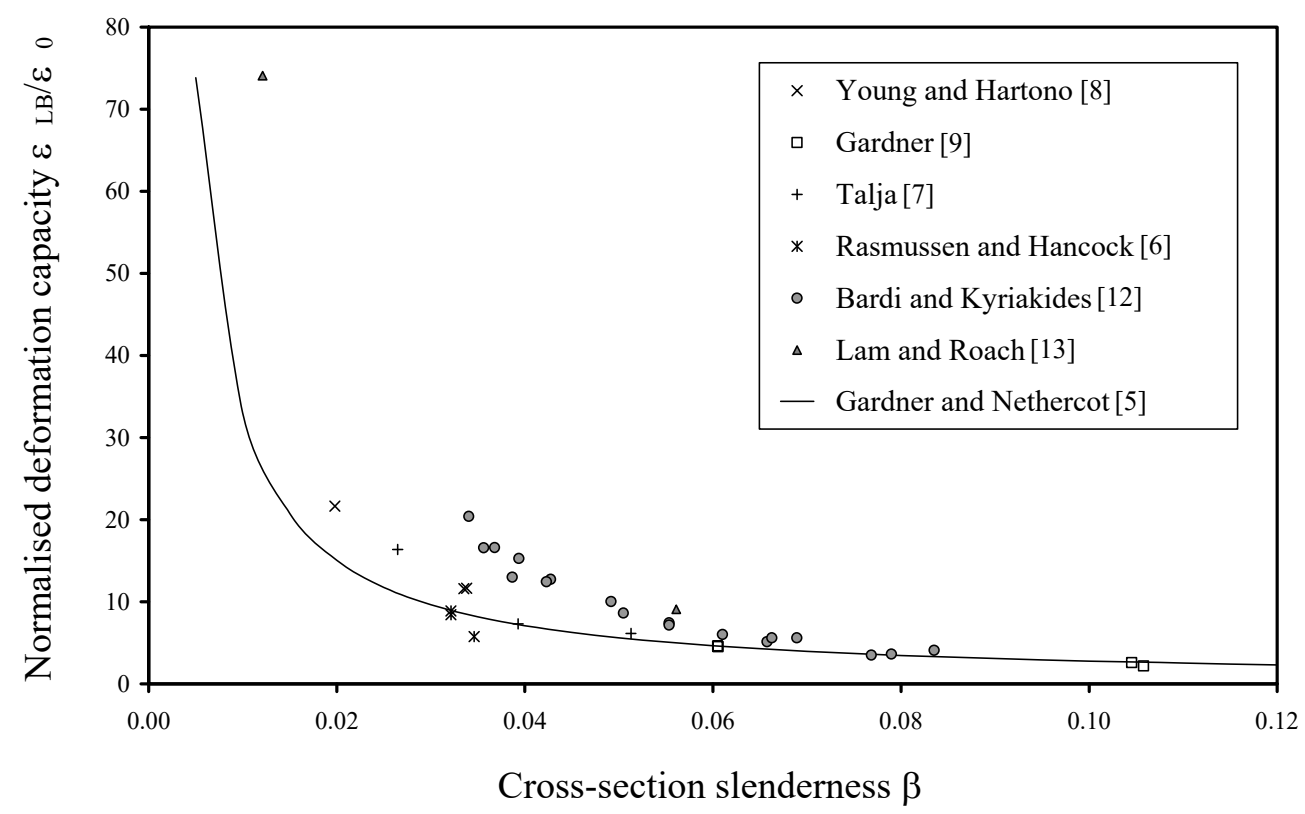

Figure 2: Deformation capacities obtained from test results. 


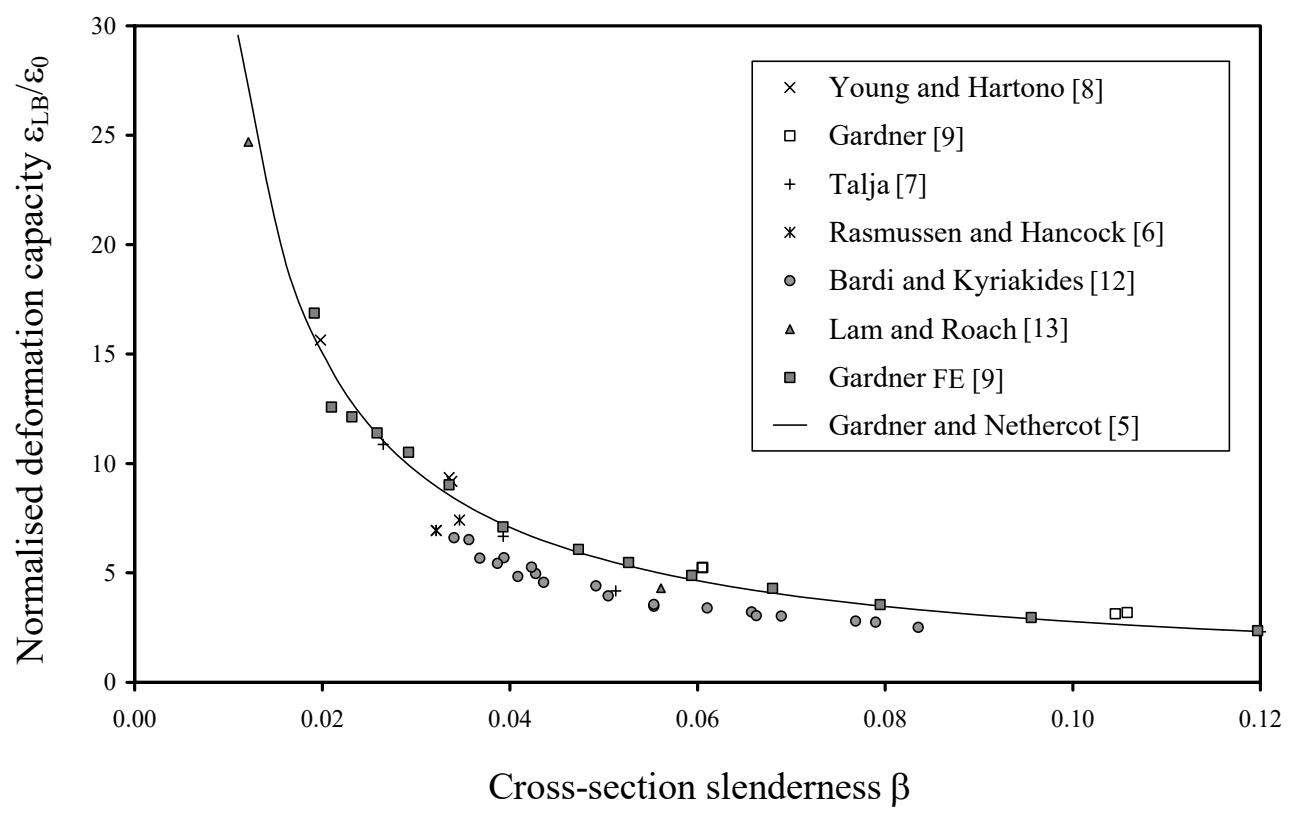

Figure 3: Deformation capacities obtained from the developed FE models.
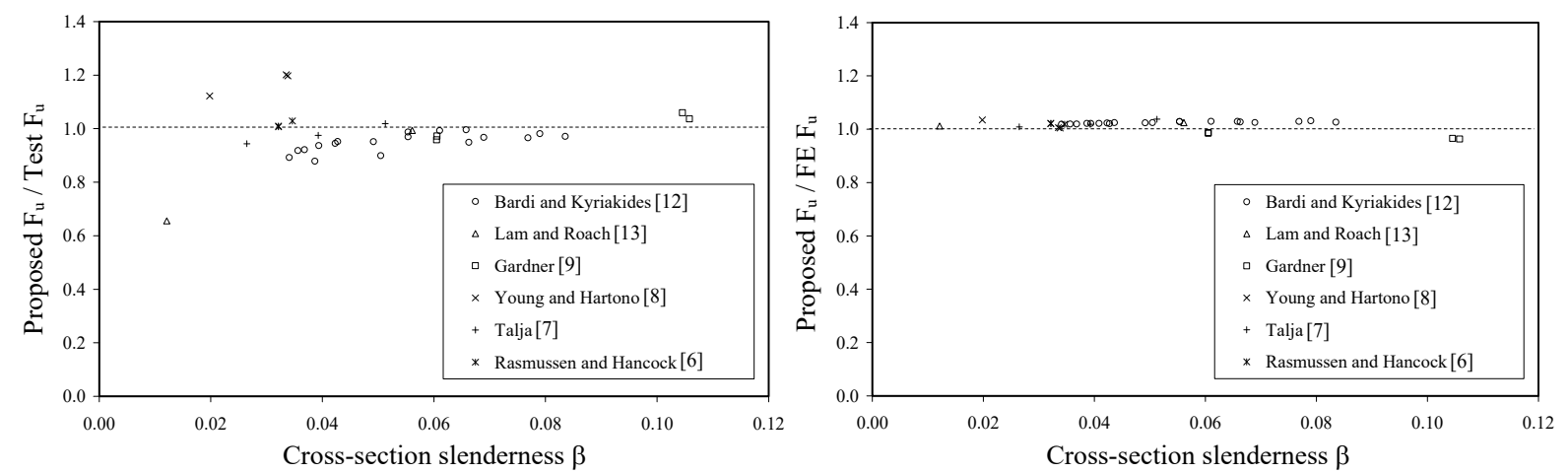

Figure 4: Performance of the proposed deformation capacity based approach for crosssections with different slenderness $\beta$ 

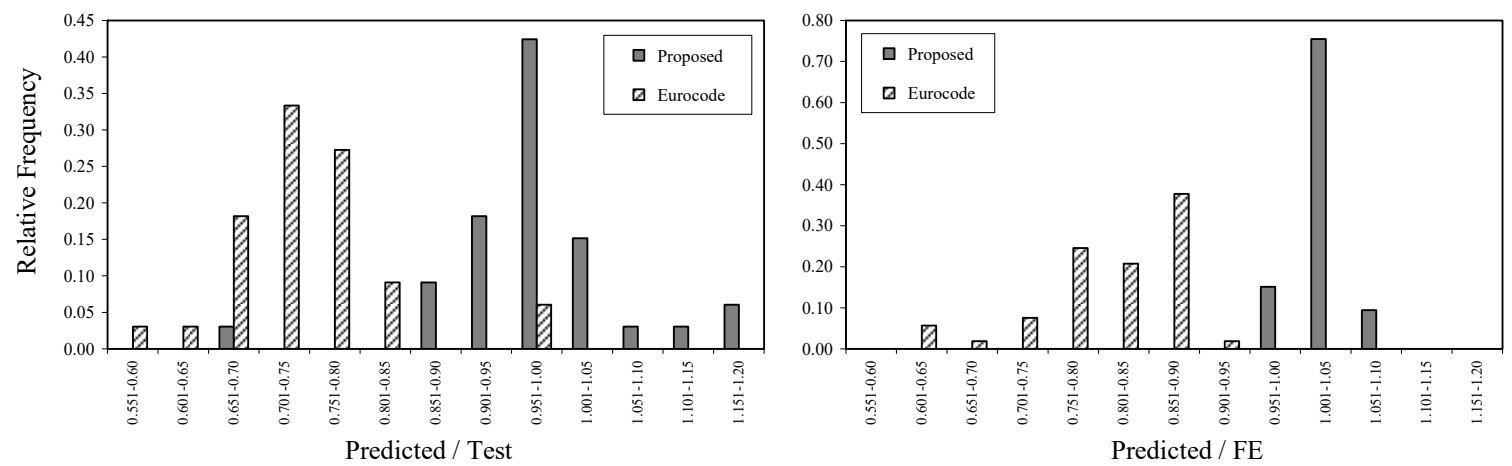

Figure 5: Frequency distributions for the compression resistance predictions using the proposed deformation capacity based approach and the Eurocode method.

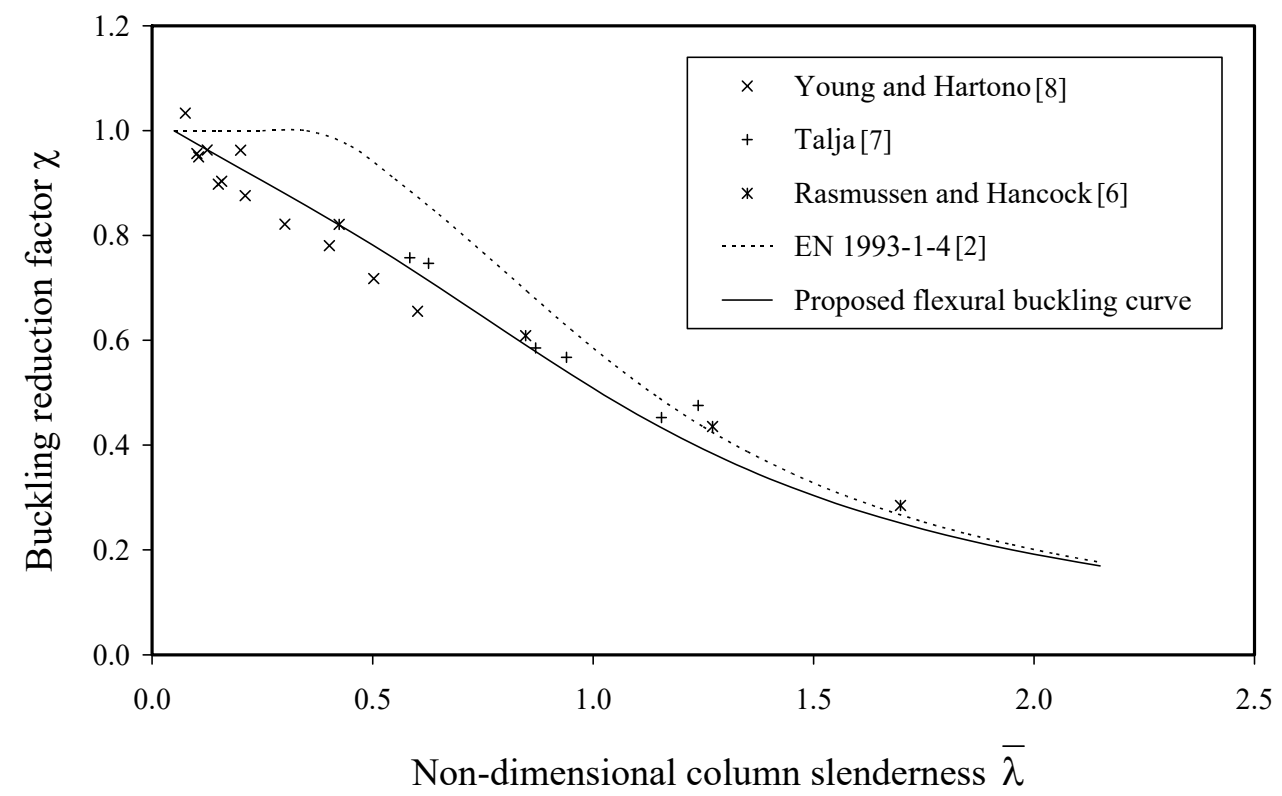

Figure 6: Proposed and Eurocode flexural buckling curves for stainless steel CHS. 


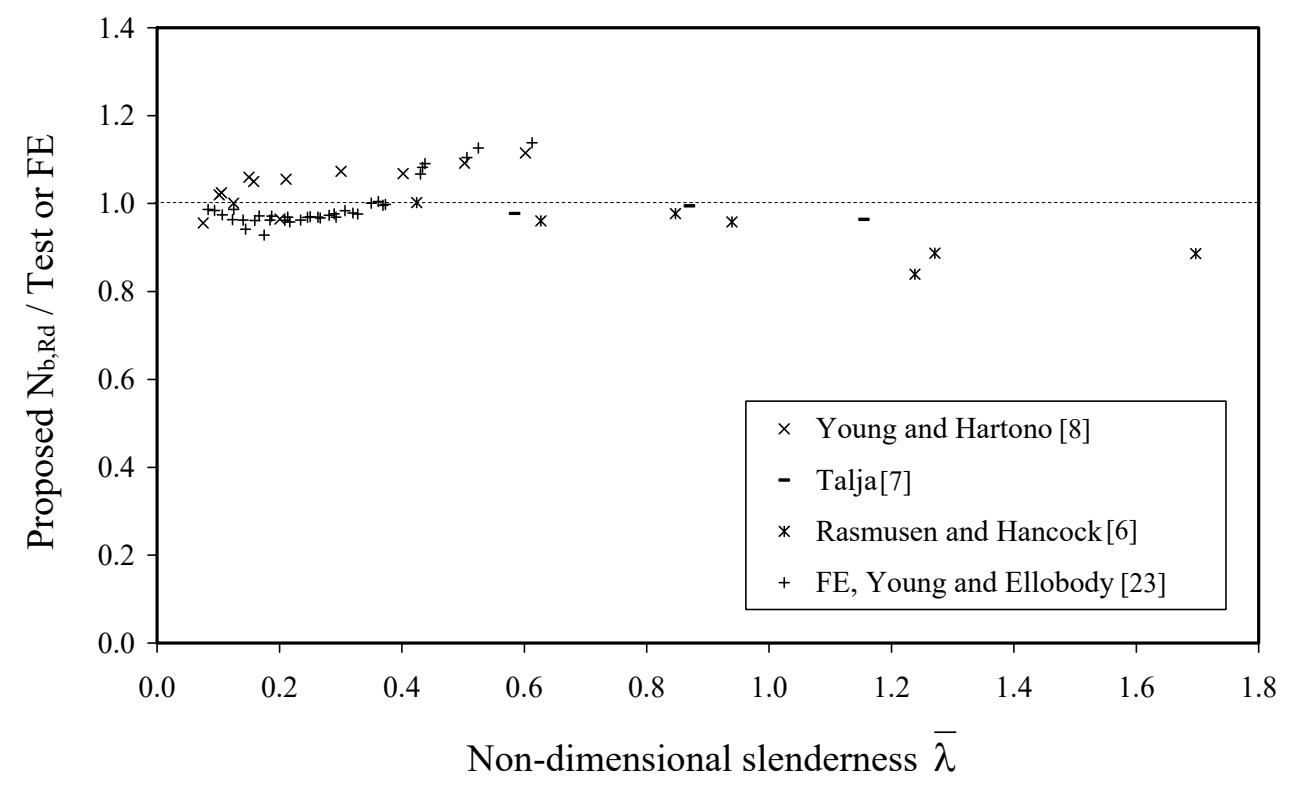

Figure 7: Performance of the proposed flexural buckling curve for all considered columns.

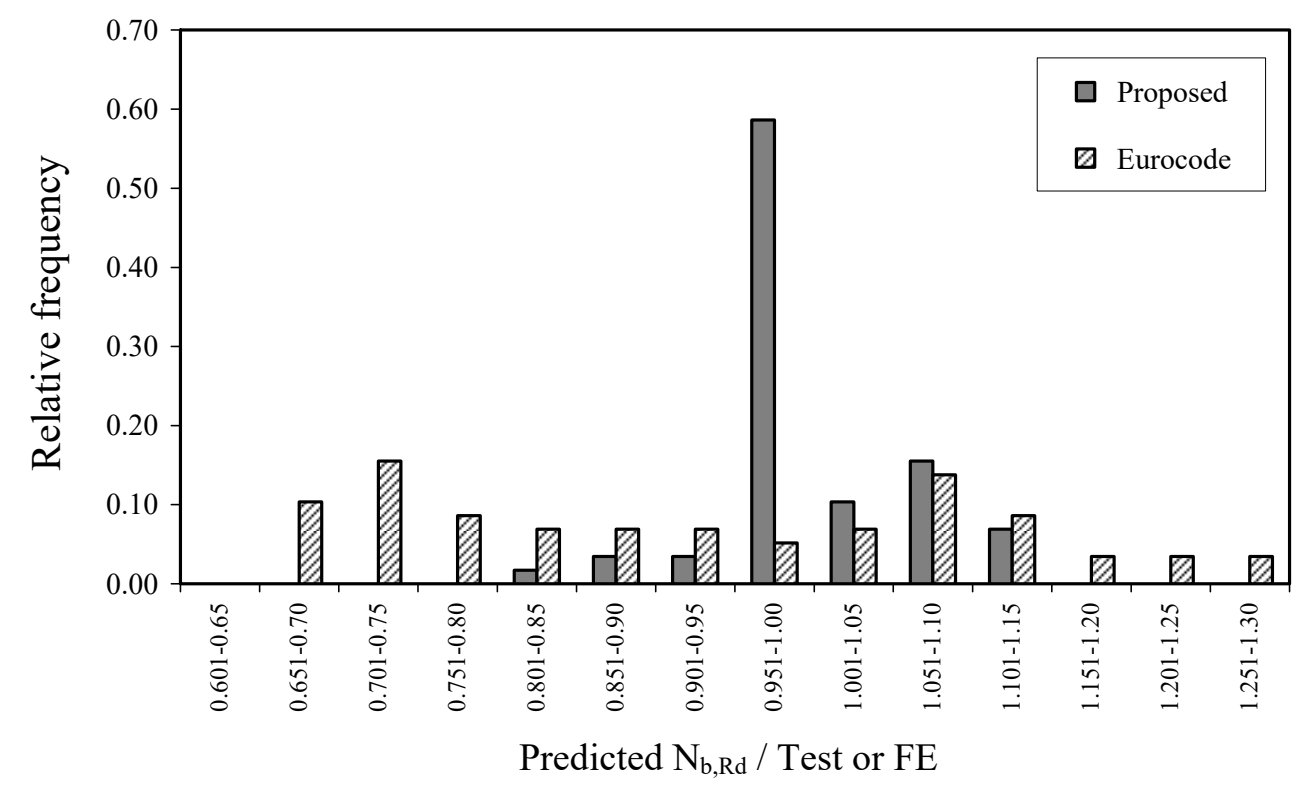

Figure 8: Frequency distributions for the predictions of flexural buckling resistances using the proposed approach and the Eurocode method. 
Table 1: Tests available from previous research on stainless steel CHS columns.

\begin{tabular}{l|cc|cc}
\hline \multirow{2}{*}{ Reference } & \multicolumn{2}{|c|}{ No. of specimens } & \multirow{2}{*}{$\begin{array}{c}\text { Stainless steel } \\
\text { grade }\end{array}$} & $\begin{array}{c}\text { Cross-section } \\
\text { slenderness } \beta\end{array}$ \\
\cline { 2 - 3 } & $\begin{array}{c}\text { Stub } \\
\text { column }\end{array}$ & $\begin{array}{c}\text { Long } \\
\text { column }\end{array}$ & EN 1.4306 & $0.032-0.035$ \\
\hline Rasmussen and Hancock [6] & 3 & 4 & EN 1.4435, & $0.026-0.051$ \\
Talja [7] & 3 & 6 & EN 1.4541 & $0.060-0.106$ \\
Gardner and Nethercot [10] & 4 & - & EN 1.4301 & $0.020-0.034$ \\
Young and Hartono [8] & 3 & 12 & EN 1.4301 & $0.034-0.084$ \\
Bardi and Kyriakides [12] & 20 & - & EN 1.4410 & $0.012-0.056$ \\
Lam and Roach [13] & 2 & - & EN 1.4401 & \\
\hline
\end{tabular}


Table 2: Predicted compression resistances for the considered CHS stub columns.

\begin{tabular}{|c|c|c|c|c|c|c|c|c|c|c|c|c|}
\hline Reference & $\begin{array}{c}\text { Cross-section } \\
\text { designation }\end{array}$ & $\begin{array}{l}\text { Material } \\
\text { grade }\end{array}$ & $\begin{array}{c}\sigma_{0.2} \\
\left(\mathrm{~N} / \mathrm{mm}^{2}\right)\end{array}$ & $\begin{array}{c}E_{0} \\
\left(\mathrm{~N} / \mathrm{mm}^{2}\right)\end{array}$ & $\begin{array}{c}\text { Test } F_{u} \\
(\mathrm{kN})\end{array}$ & $\varepsilon_{\mathrm{LB}} / \varepsilon_{0}$ & $\begin{array}{c}\sigma_{\mathrm{LB}} \\
\left(\mathrm{N} / \mathrm{mm}^{2}\right)\end{array}$ & $\begin{array}{l}\text { Prop } F_{u} \\
/ \text { Test } F_{u}\end{array}$ & $\begin{array}{l}\text { Prop } F_{u} \\
/ F F_{u}\end{array}$ & Class & $\begin{array}{l}\mathrm{EN} \mathrm{F}_{\mathrm{u}} / \\
\text { Test } \mathrm{F}_{\mathrm{u}}\end{array}$ & $\begin{array}{c}\mathrm{EN} \mathrm{F}_{\mathrm{u}} / \\
\mathrm{FE} \mathrm{F}_{\mathrm{u}}\end{array}$ \\
\hline \multirow{20}{*}{$\begin{array}{c}\text { Bardi and } \\
\text { Kyriakides } \\
{[12]}\end{array}$} & $58.4 \times 2.55$ & \multirow{20}{*}{$\begin{array}{l}\text { EN } 1.4410 \\
\text { (Duplex) }\end{array}$} & 605 & 194500 & 363 & 8.42 & 725 & 0.89 & 1.02 & 2 & 0.75 & 0.85 \\
\hline & $57.6 \times 2.19$ & & 605 & 194500 & 292 & 7.21 & 719 & 0.94 & 1.02 & 3 & 0.79 & 0.86 \\
\hline & $57.2 \times 2.10$ & & 605 & 194500 & - & 6.93 & 717 & - & 1.02 & 3 & - & 0.86 \\
\hline & $57.2 \times 2.01$ & & 605 & 194500 & 262 & 6.61 & 715 & 0.95 & 1.02 & 3 & 0.81 & 0.86 \\
\hline & $57.2 \times 1.97$ & & 605 & 194500 & - & 6.47 & 714 & - & 1.02 & 3 & - & 0.87 \\
\hline & $56.7 \times 1.74$ & & 605 & 194500 & 224 & 5.70 & 709 & 0.95 & 1.02 & 4 & 0.81 & 0.87 \\
\hline & $56.3 \times 1.54$ & & 605 & 194500 & 189 & 5.05 & 703 & 0.99 & 1.03 & 4 & 0.85 & 0.88 \\
\hline & $55.8 \times 1.29$ & & 605 & 194500 & 154 & 4.23 & 694 & 1.00 & 1.03 & 4 & 0.80 & 0.82 \\
\hline & $55.7 \times 1.23$ & & 605 & 194500 & 150 & 4.03 & 692 & 0.97 & 1.03 & 4 & 0.76 & 0.80 \\
\hline & $55.4 \times 1.10$ & & 605 & 194500 & 133 & 3.61 & 686 & 0.97 & 1.03 & 4 & 0.72 & 0.77 \\
\hline & $55.4 \times 1.07$ & & 605 & 194500 & 127 & 3.51 & 684 & 0.98 & 1.03 & 4 & 0.73 & 0.76 \\
\hline & $58.1 \times 2.38$ & & 622 & 197900 & 335 & 7.74 & 742 & 0.92 & 1.02 & 2 & 0.77 & 0.85 \\
\hline & $57.3 \times 2.04$ & & 561 & 196500 & 268 & 7.35 & 664 & 0.88 & 1.02 & 3 & 0.74 & 0.86 \\
\hline & $56.4 \times 1.55$ & & 561 & 196500 & 194 & 5.55 & 653 & 0.90 & 1.02 & 4 & 0.77 & 0.88 \\
\hline & $56.2 \times 1.41$ & & 622 & 197900 & 175 & 4.56 & 718 & 0.99 & 1.03 & 4 & 0.81 & 0.84 \\
\hline & $58.1 \times 2.43$ & & 605 & 194500 & 334 & 8.02 & 723 & 0.92 & 1.02 & 2 & 0.77 & 0.85 \\
\hline & $57.2 \times 2.03$ & & 605 & 194500 & 266 & 6.68 & 715 & 0.95 & 1.02 & 3 & 0.80 & 0.87 \\
\hline & $56.3 \times 1.54$ & & 605 & 194500 & 192 & 5.05 & 703 & 0.97 & 1.03 & 4 & 0.83 & 0.88 \\
\hline & $55.8 \times 1.28$ & & 605 & 194500 & 160 & 4.19 & 694 & 0.95 & 1.03 & 4 & 0.76 & 0.82 \\
\hline & $55.2 \times 1.01$ & & 605 & 194500 & 121 & 3.32 & 681 & 0.97 & 1.03 & 4 & 0.70 & 0.74 \\
\hline
\end{tabular}


Table 2 (Contd.): Predicted compression resistances for the considered CHS stub columns.

\begin{tabular}{|c|c|c|c|c|c|c|c|c|c|c|c|c|}
\hline Reference & $\begin{array}{c}\text { Cross-section } \\
\text { designation }\end{array}$ & $\begin{array}{l}\text { Material } \\
\text { grade }\end{array}$ & $\begin{array}{c}\sigma_{0.2} \\
\left(\mathrm{~N} / \mathrm{mm}^{2}\right)\end{array}$ & $\begin{array}{c}\mathrm{E}_{0} \\
\left(\mathrm{~N} / \mathrm{mm}^{2}\right)\end{array}$ & $\begin{array}{c}\text { Test } F_{u} \\
(\mathrm{kN})\end{array}$ & $\varepsilon_{\mathrm{LB}} / \varepsilon_{0}$ & $\begin{array}{c}\sigma_{\mathrm{LB}} \\
\left(\mathrm{N} / \mathrm{mm}^{2}\right)\end{array}$ & $\begin{array}{l}\text { Prop } F_{u} \\
/ \text { Test } F_{u}\end{array}$ & $\begin{array}{l}\text { Prop } F_{u} \\
/ \text { FE F }_{u}\end{array}$ & Class & $\begin{array}{l}\text { EN F }_{\mathrm{u}} / \\
\text { Test } \mathrm{F}_{\mathrm{u}}\end{array}$ & $\begin{array}{c}\mathrm{EN} \mathrm{F}_{\mathrm{u}} / \\
\mathrm{FE} \mathrm{F}_{\mathrm{u}}\end{array}$ \\
\hline \multirow{2}{*}{$\begin{array}{c}\text { Lam and } \\
\text { Roach [13] }\end{array}$} & $104.0 \times 2.00$ & \multirow{2}{*}{$\begin{array}{c}\text { EN } 1.4401 \\
\text { (Austenitic) }\end{array}$} & 440 & 200000 & 328 & 4.98 & 509 & 0.99 & 1.02 & 4 & 0.84 & 0.87 \\
\hline & $114.0 \times 6.02$ & & 270 & 200000 & 1062 & 26.50 & 341 & 0.66 & 1.01 & 1 & 0.52 & 0.80 \\
\hline \multirow{3}{*}{$\begin{array}{l}\text { Young and } \\
\text { Hartono [8] }\end{array}$} & $90.0 \times 2.75$ & \multirow{3}{*}{$\begin{array}{c}\text { EN } 1.4301 \\
\text { (Austenitic) }\end{array}$} & 270 & 190000 & 235 & 15.22 & 338 & 1.12 & 1.03 & 1 & 0.90 & 0.83 \\
\hline & $170.0 \times 3.50$ & & 288 & 195000 & 496 & 8.56 & 338 & 1.20 & 1.01 & 2 & 1.02 & 0.86 \\
\hline & $170 \times 3.50$ & & 288 & 195000 & 492 & 8.48 & 338 & 1.20 & 1.00 & 2 & 1.02 & 0.86 \\
\hline \multirow{4}{*}{$\begin{array}{c}\text { Gardner and } \\
\text { Nethercot } \\
{[10]}\end{array}$} & $103.0 \times 1.50$ & \multirow{4}{*}{$\begin{array}{l}\text { EN } 1.4301 \\
\text { (Austenitic) }\end{array}$} & 368 & 206000 & 214 & 4.60 & 434 & 0.97 & 0.99 & 4 & 0.77 & 0.78 \\
\hline & $103.0 \times 1.50$ & & 368 & 206000 & 217 & 4.60 & 435 & 0.96 & 0.99 & 4 & 0.76 & 0.78 \\
\hline & $153.0 \times 1.50$ & & 405 & 203000 & 287 & 2.63 & 437 & 1.04 & 0.96 & 4 & 0.68 & 0.64 \\
\hline & $153.0 \times 1.50$ & & 405 & 203000 & 286 & 2.66 & 438 & 1.06 & 0.97 & 4 & 0.70 & 0.64 \\
\hline \multirow{3}{*}{ Talja [7] } & $140.0 \times 2.00$ & EN 1.4435 & 294 & 200000 & 278 & 5.46 & 333 & 1.02 & 1.04 & 4 & 0.90 & 0.92 \\
\hline & $140.0 \times 3.00$ & EN 1.4435 & 317 & 192000 & 468 & 7.23 & 371 & 0.98 & 1.02 & 3 & 0.83 & 0.87 \\
\hline & $140.0 \times 4.00$ & EN 1.4541 & 309 & 197000 & 665 & 11.05 & 372 & 0.94 & 1.01 & 1 & 0.78 & 0.84 \\
\hline \multirow{3}{*}{$\begin{array}{c}\text { Rasmussen } \\
\text { and } \\
\text { Hancock [6] }\end{array}$} & $101.6 \times 2.85$ & \multirow{3}{*}{$\begin{array}{l}\text { EN } 1.4306 \\
\text { (Austenitic) }\end{array}$} & 390 & 202000 & 426 & 8.96 & 468 & 1.01 & 1.02 & 2 & 0.84 & 0.85 \\
\hline & $101.6 \times 2.85$ & & 390 & 202000 & 425 & 8.96 & 468 & 1.01 & 1.02 & 2 & 0.84 & 0.85 \\
\hline & $101.6 \times 2.85$ & & 390 & 202000 & 391 & 8.27 & 466 & 1.03 & 1.02 & 2 & 0.86 & 0.85 \\
\hline & & & & & & & Average & 0.98 & 1.02 & & 0.80 & 0.83 \\
\hline & & & & & & & $\mathrm{COV}$ & 0.09 & 0.02 & & 0.12 & 0.07 \\
\hline
\end{tabular}


Table 3: Predicted flexural buckling resistances for the considered test results on CHS long columns.

\begin{tabular}{|c|c|c|c|c|c|c|c|c|c|c|c|c|}
\hline Reference & $\begin{array}{c}\text { Cross-section } \\
\text { designation }\end{array}$ & $\begin{array}{c}\mathrm{L}_{\mathrm{e}} \\
(\mathrm{mm})\end{array}$ & $\begin{array}{c}\text { Material } \\
\text { Grade }\end{array}$ & $\begin{array}{c}\sigma_{0.2} \\
\left(\mathrm{~N} / \mathrm{mm}^{2}\right)\end{array}$ & $\begin{array}{c}\mathrm{E}_{0} \\
\left(\mathrm{~N} / \mathrm{mm}^{2}\right)\end{array}$ & $\begin{array}{c}\text { Test } F_{u} \\
(\mathrm{kN})\end{array}$ & $\begin{array}{c}\sigma_{\text {eff }} \\
\left(\mathrm{N} / \mathrm{mm}^{2}\right)\end{array}$ & $\bar{\lambda}$ & $\begin{array}{l}\text { Prop. } \mathrm{F}_{\mathrm{u}} \\
/ \text { Test } \mathrm{F}_{\mathrm{u}}\end{array}$ & Class & $\bar{\lambda}$ & $\begin{array}{l}\text { EN } F_{u} \\
\text { Test } F_{u}\end{array}$ \\
\hline \multirow{12}{*}{$\begin{array}{l}\text { Young and } \\
\text { Hartono [8] }\end{array}$} & $89.0 \times 2.71$ & 500 & \multirow{12}{*}{$\begin{array}{c}\mathrm{EN} \\
1.4301\end{array}$} & 268 & 190000 & 198 & 281 & 0.20 & 0.96 & 1 & 0.20 & 0.99 \\
\hline & $89.2 \times 2.83$ & 750 & & 268 & 190000 & 177 & 281 & 0.30 & 1.07 & 1 & 0.29 & 1.16 \\
\hline & $89.0 \times 2.78$ & 1001 & & 268 & 190000 & 165 & 281 & 0.40 & 1.07 & 1 & 0.39 & 1.22 \\
\hline & $88.9 \times 2.78$ & 1250 & & 268 & 190000 & 152 & 281 & 0.50 & 1.09 & 1 & 0.49 & 1.26 \\
\hline & $88.9 \times 2.68$ & 1501 & & 268 & 190000 & 133 & 280 & 0.60 & 1.12 & 1 & 0.59 & 1.29 \\
\hline & $168.5 \times 3.31$ & 500 & & 285 & 195000 & 475 & 291 & 0.11 & 1.02 & 2 & 0.10 & 1.03 \\
\hline & $168.8 \times 3.37$ & 750 & & 285 & 195000 & 461 & 292 & 0.16 & 1.05 & 2 & 0.16 & 1.08 \\
\hline & $168.7 \times 3.26$ & 1002 & & 285 & 195000 & 432 & 291 & 0.21 & 1.06 & 2 & 0.21 & 1.12 \\
\hline & $322.5 \times 4.25$ & 750 & & 255 & 202000 & 1120 & 255 & 0.08 & 0.96 & 3 & 0.08 & 0.97 \\
\hline & $320.4 \times 4.48$ & 1000 & & 255 & 202000 & 1088 & 256 & 0.10 & 1.02 & 3 & 0.10 & 1.04 \\
\hline & $324.1 \times 4.24$ & 1249 & & 255 & 202000 & 1046 & 255 & 0.12 & 1.00 & 3 & 0.12 & 1.04 \\
\hline & $324.3 \times 4.38$ & 1499 & & 255 & 202000 & 1010 & 255 & 0.15 & 1.06 & 3 & 0.15 & 1.11 \\
\hline \multirow{6}{*}{ Talja [7] } & $139.8 \times 1.95$ & 2250 & \multirow{3}{*}{$\begin{array}{c}\mathrm{EN} \\
1.4435\end{array}$} & 294 & 200000 & 202 & 316 & 0.58 & 0.98 & 4 & 0.56 & 1.10 \\
\hline & $139.8 \times 1.95$ & 3350 & & 294 & 200000 & 156 & 316 & 0.87 & 0.99 & 4 & 0.84 & 1.12 \\
\hline & $139.9 \times 1.97$ & 4449 & & 294 & 200000 & 122 & 316 & 1.15 & 0.96 & 4 & 1.11 & 1.05 \\
\hline & $140.0 \times 3.99$ & 2251 & \multirow{3}{*}{$\begin{array}{c}\mathrm{EN} \\
1.4541\end{array}$} & 309 & 194000 & 437 & 343 & 0.63 & 0.96 & 1 & 0.59 & 1.06 \\
\hline & $139.1 \times 3.99$ & 3350 & & 309 & 194000 & 330 & 343 & 0.94 & 0.96 & 1 & 0.89 & 1.05 \\
\hline & $140.1 \times 3.98$ & 4450 & & 309 & 194000 & 278 & 343 & 1.24 & 0.84 & 2 & 1.17 & 0.90 \\
\hline \multirow{4}{*}{$\begin{array}{c}\text { Rasmussen } \\
\text { and Hancock } \\
{[6]}\end{array}$} & $101.4 \times 2.98$ & 1000 & \multirow{4}{*}{$\begin{array}{c}\mathrm{EN} \\
1.4306\end{array}$} & 390 & 202000 & 328 & 434 & 0.42 & 1.00 & 2 & 0.40 & 1.09 \\
\hline & $101.5 \times 2.95$ & 2001 & & 390 & 202000 & 241 & 434 & 0.85 & 0.98 & 2 & 0.80 & 1.08 \\
\hline & $101.4 \times 2.93$ & 3000 & & 390 & 202000 & 171 & 434 & 1.27 & 0.89 & 2 & 1.21 & 0.95 \\
\hline & $101.3 \times 2.96$ & 4000 & & 390 & 202000 & 113 & 434 & 1.70 & 0.89 & 2 & 1.61 & 0.92 \\
\hline & & & & & & & & Average & 1.00 & & & 1.07 \\
\hline & & & & & & & & $\mathrm{COV}$ & 0.07 & & & 0.09 \\
\hline
\end{tabular}


Table 4: Predicted flexural buckling resistances for the considered FE results on CHS long columns (Young and Ellobody [23]).

\begin{tabular}{|c|c|c|c|c|c|c|c|c|c|c|c|}
\hline $\begin{array}{c}\text { Cross-section } \\
\text { designation }\end{array}$ & $\begin{array}{c}\mathrm{L}_{\mathrm{e}} \\
(\mathrm{mm}) \\
\end{array}$ & $\begin{array}{c}\text { Material } \\
\text { Grade }\end{array}$ & $\begin{array}{c}\sigma_{0.2} \\
\left(\mathrm{~N} / \mathrm{mm}^{2}\right)\end{array}$ & $\begin{array}{c}E_{0} \\
\left(\mathrm{~N} / \mathrm{mm}^{2}\right) \\
\end{array}$ & $\begin{array}{c}\mathrm{FE} \mathrm{F}_{\mathrm{u}} \\
(\mathrm{kN})\end{array}$ & $\begin{array}{c}\sigma_{\text {eff }} \\
\left(\mathrm{N} / \mathrm{mm}^{2}\right)\end{array}$ & $\bar{\lambda}$ & $\begin{array}{l}\text { Prop. } \mathrm{F}_{\mathrm{u}} \\
/ \mathrm{FE} \mathrm{F}_{\mathrm{u}}\end{array}$ & Class & $\bar{\lambda}$ & $\begin{array}{c}\mathrm{EN} \mathrm{F}_{\mathrm{u}} / \\
\mathrm{FE} \mathrm{F}_{\mathrm{u}}\end{array}$ \\
\hline $100.0 \times 1.00$ & 500 & \multirow{6}{*}{$\begin{array}{c}\mathrm{EN} \\
1.4301\end{array}$} & \multirow{6}{*}{268} & \multirow{6}{*}{190000} & 88.6 & 281 & 0.18 & 0.93 & 4 & 0.16 & 0.85 \\
\hline $100.0 \times 1.00$ & 750 & & & & 81.2 & 281 & 0.26 & 0.97 & 4 & 0.24 & 0.93 \\
\hline $100.0 \times 1.00$ & 1000 & & & & 75.0 & 281 & 0.35 & 1.00 & 4 & 0.33 & 1.01 \\
\hline $100.0 \times 1.00$ & 1250 & & & & 65.4 & 281 & 0.44 & 1.09 & 4 & 0.41 & 1.15 \\
\hline $100.0 \times 1.00$ & 1500 & & & & 59.9 & 281 & 0.53 & 1.13 & 4 & 0.49 & 1.19 \\
\hline $100.0 \times 1.00$ & 1750 & & & & 55.7 & 281 & 0.61 & 1.14 & 4 & 0.57 & 1.21 \\
\hline $120.0 \times 1.00$ & 500 & \multirow{6}{*}{$\begin{array}{c}\mathrm{EN} \\
1.4301\end{array}$} & \multirow{6}{*}{268} & \multirow{6}{*}{190000} & 105.1 & 277 & 0.14 & 0.94 & 4 & 0.13 & 0.79 \\
\hline $120.0 \times 1.00$ & 750 & & & & 99.6 & 277 & 0.22 & 0.96 & 4 & 0.19 & 0.83 \\
\hline $120.0 \times 1.00$ & 1000 & & & & 94.2 & 277 & 0.29 & 0.98 & 4 & 0.26 & 0.88 \\
\hline $120.0 \times 1.00$ & 1250 & & & & 88.0 & 277 & 0.36 & 1.00 & 4 & 0.32 & 0.94 \\
\hline $120.0 \times 1.00$ & 1500 & & & & 78.3 & 277 & 0.43 & 1.08 & 4 & 0.39 & 1.06 \\
\hline $120.0 \times 1.00$ & 1750 & & & & 73.3 & 277 & 0.51 & 1.10 & 4 & 0.45 & 1.09 \\
\hline $140.0 \times 1.00$ & 500 & \multirow{6}{*}{$\begin{array}{c}\mathrm{EN} \\
1.4301\end{array}$} & \multirow{6}{*}{268} & \multirow{6}{*}{190000} & 119.5 & 273 & 0.12 & 0.96 & 4 & 0.11 & 0.75 \\
\hline $140.0 \times 1.00$ & 750 & & & & 116.1 & 273 & 0.18 & 0.96 & 4 & 0.16 & 0.77 \\
\hline $140.0 \times 1.00$ & 1000 & & & & 111.8 & 273 & 0.25 & 0.97 & 4 & 0.21 & 0.80 \\
\hline $140.0 \times 1.00$ & 1250 & & & & 106.6 & 273 & 0.31 & 0.98 & 4 & 0.27 & 0.84 \\
\hline $140.0 \times 1.00$ & 1500 & & & & 101.8 & 273 & 0.37 & 1.00 & 4 & 0.32 & 0.88 \\
\hline $140.0 \times 1.00$ & 1750 & & & & 91.7 & 273 & 0.43 & 1.07 & 4 & 0.37 & 0.98 \\
\hline $160.0 \times 1.00$ & 500 & \multirow{6}{*}{$\begin{array}{c}\mathrm{EN} \\
1.4301\end{array}$} & \multirow{6}{*}{268} & \multirow{6}{*}{190000} & 134.1 & 269 & 0.11 & 0.97 & 4 & 0.09 & 0.71 \\
\hline $160.0 \times 1.00$ & 750 & & & & 132.4 & 269 & 0.16 & 0.96 & 4 & 0.14 & 0.72 \\
\hline $160.0 \times 1.00$ & 1000 & & & & 127.9 & 269 & 0.21 & 0.97 & 4 & 0.18 & 0.75 \\
\hline $160.0 \times 1.00$ & 1250 & & & & 124.8 & 269 & 0.27 & 0.97 & 4 & 0.23 & 0.77 \\
\hline $160.0 \times 1.00$ & 1500 & & & & 119.9 & 269 & 0.32 & 0.98 & 4 & 0.27 & 0.80 \\
\hline $160.0 \times 1.00$ & 1750 & & & & 114.1 & 269 & 0.37 & 1.00 & 4 & 0.32 & 0.84 \\
\hline
\end{tabular}


Table 4 (Contd.): Predicted flexural buckling resistances for the considered FE results on CHS long columns (Young and Ellobody [23]).

\begin{tabular}{|c|c|c|c|c|c|c|c|c|c|c|c|}
\hline $\begin{array}{c}\text { Cross-section } \\
\text { designation }\end{array}$ & $\begin{array}{c}\mathrm{L}_{\mathrm{e}} \\
(\mathrm{mm})\end{array}$ & $\begin{array}{l}\text { Material } \\
\text { Grade }\end{array}$ & $\begin{array}{c}\sigma_{0.2} \\
\left(\mathrm{~N} / \mathrm{mm}^{2}\right)\end{array}$ & $\begin{array}{c}E_{0} \\
\left(\mathrm{~N} / \mathrm{mm}^{2}\right)\end{array}$ & $\begin{array}{c}\mathrm{FE} \mathrm{F}_{\mathrm{u}} \\
(\mathrm{kN})\end{array}$ & $\begin{array}{c}\sigma_{\text {eff }} \\
\left(\mathrm{N} / \mathrm{mm}^{2}\right)\end{array}$ & $\bar{\lambda}$ & $\begin{array}{l}\text { Prop. } F_{u} \\
/ \text { FE } F_{u}\end{array}$ & Class & $\bar{\lambda}$ & $\begin{array}{c}\mathrm{EN} \mathrm{F}_{\mathrm{u}} / \\
\mathrm{FE} \mathrm{F}_{\mathrm{u}}\end{array}$ \\
\hline $180.0 \times 1.00$ & 500 & \multirow{6}{*}{$\begin{array}{c}\mathrm{EN} \\
1.4301\end{array}$} & \multirow{6}{*}{268} & \multirow{6}{*}{190000} & 147.4 & 264 & 0.09 & 0.98 & 4 & 0.08 & 0.69 \\
\hline $180.0 \times 1.00$ & 750 & & & & 147.3 & 264 & 0.14 & 0.96 & 4 & 0.12 & 0.69 \\
\hline $180.0 \times 1.00$ & 1000 & & & & 142.6 & 264 & 0.19 & 0.97 & 4 & 0.16 & 0.71 \\
\hline $180.0 \times 1.00$ & 1250 & & & & 140.6 & 264 & 0.23 & 0.96 & 4 & 0.19 & 0.72 \\
\hline $180.0 \times 1.00$ & 1500 & & & & 135.7 & 264 & 0.28 & 0.97 & 4 & 0.23 & 0.75 \\
\hline $180.0 \times 1.00$ & 1750 & & & & 132.0 & 264 & 0.33 & 0.98 & 4 & 0.27 & 0.77 \\
\hline $200.0 \times 1.00$ & 500 & \multirow{6}{*}{$\begin{array}{c}\mathrm{EN} \\
1.4301\end{array}$} & \multirow{6}{*}{268} & \multirow{6}{*}{190000} & 157.9 & 258 & 0.08 & 0.99 & 4 & 0.07 & 0.68 \\
\hline $200.0 \times 1.00$ & 750 & & & & 157.9 & 258 & 0.13 & 0.99 & 4 & 0.10 & 0.68 \\
\hline $200.0 \times 1.00$ & 1000 & & & & 156.9 & 258 & 0.17 & 0.97 & 4 & 0.14 & 0.68 \\
\hline $200.0 \times 1.00$ & 1250 & & & & 155.3 & 258 & 0.21 & 0.96 & 4 & 0.17 & 0.69 \\
\hline $200.0 \times 1.00$ & 1500 & & & & 150.8 & 258 & 0.25 & 0.97 & 4 & 0.20 & 0.71 \\
\hline $200.0 \times 1.00$ & 1750 & & & & 147.7 & 258 & 0.29 & 0.97 & 4 & 0.24 & 0.73 \\
\hline & & & & & & & Average & 0.99 & & & 0.84 \\
\hline & & & & & & & $\mathrm{COV}$ & 0.05 & & & 0.18 \\
\hline
\end{tabular}

